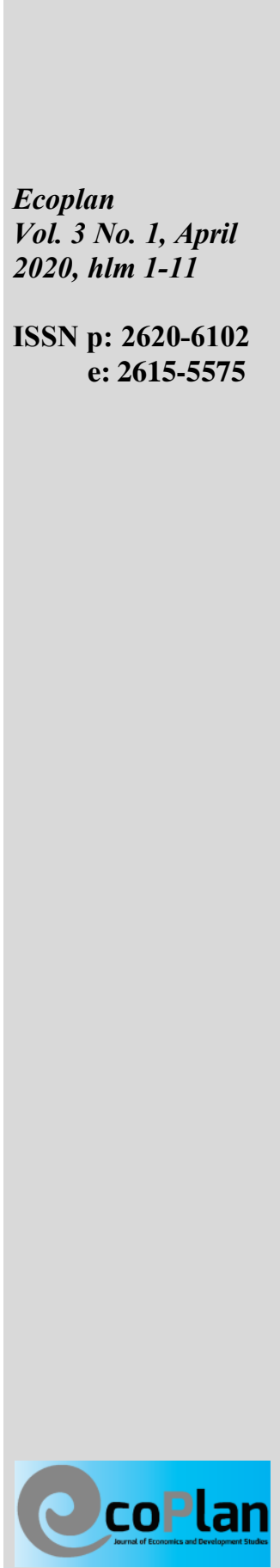

Jl. H. Hasan Basry No.29, Pangeran, Banjarmasin Utara, Kota Banjarmasin, Kalimantan Selatan E-mail: ecoplan@ulm.ac.id

\section{ANALISIS PENGEMBANGAN EKSPOR KAYU MANIS INDONESIA}

\author{
Isro'iyatul Mubarokah' ${ }^{1)}$, Ely Nurhayati ${ }^{2)}$ \\ Universitas Singaperbangsa Karawang ${ }^{1)}$, Universitas Yarsi ${ }^{2)}$ \\ *E-mail corresponding author: isroiyatul.mubarokah@fe.unsika.ac.id
}

Abstract - Export is an important component in the economy of the country. The higher the country's export performance, the greater positive effect in increasing of economic growth. From 2012 to 2016, Indonesia's exports continued to decline. Considering these conditions, Indonesia needs to make a strategic effort to increase its export performance, of course. One of the efforts which can be done is conducting export development. As an agricultural country, one of potential commodities used to increase exports is cinnamon. This research will analyze the cinnamon export markets which are potentially to be developed. Moreover, this research will find out the factors that influence the export of these commodities. The methods used are RCA, EPD, X-Model, and Gravity. The result of analysis shows that cinnamon has optimistic markets to be developed in Malaysia, Canada, Netherlands, Brazil, the United States of America, and The Republic of Dominican. Meanwhile, the potential markets to be developed are the United Arab Emirates, Germany and Algeria. The factors affecting exports are gross national product per capita, population, export prices and economic distance.

Keywords: EPD, Cinnamon, Gravity Model, Export Development, RCA

\section{THE ANALYSIS OF THE EXPORT DEVELOPMENT OF INDONESIAN CINNAMON}

Abstrak- Ekspor merupakan salah satu komponen penting dalam perekonomian negara. Semakin tinggi kinerja ekspor negara, semakin besar pula dampak positifnya terhadap peningkatan pertumbuhan ekonomi. Sejak tahun 2012 hingga 2016, ekspor indonesia terus mengalami penurunan. Melihat kondisi tersebut, tentunya Indonesia perlu melakukan upaya strategis untuk meningkatkan kembali kinerja ekspornya. Salah satu upaya yang dapat dilakukan adalah dengan melakukan pengembangan ekspor. Sebagai negara agraris, salah satu komoditas yang dapat digunakan untuk meningkatkan ekspor adalah kayu manis. Penelitian ini akan menganalisis pasar ekspor kayu manis yang potensial untuk dikembangkan, serta mengetahui faktor-faktor yang mempengaruhi ekspor komoditas tersebut. Metode yang digunakan adalah metode RCA, EPD, X-Model, dan Gravity. Hasil analisis menunjukkan bahwa pasar optimis untuk dikembangkan adalah Malaysia, Kanada, Belanda, Brazil, Amerika Serikat dan Republik Dominika. Sedangkan pasar yang potensial untuk dikembangkan adalah Uni Emirat Arab, Jerman dan Aljazair. Faktor-faktor yang mempengaruhi ekspor adalah produk nasional bruto per kapita, populasi, harga ekspor dan jarak ekonomi.

Kata kunci : EPD, Kayu Manis, Model Gravity, Pengembangan Ekspor, RCA. 


\section{PENDAHULUAN}

Ekspor merupakan salah satu komponen penting dalam perekonomian suatu negara. Semakin tinggi kinerja ekspor negara, semakin besar pula dampak positifnya perekonomian negara. Secara eksplisit ekspor digunakan sebagai salah satu komponen dalam perhitungan Produk Domestik Bruto (PDB), sehingga ekspor menjadi salah satu faktor yang paling berkontribusi terhadap PDB. Selain meningkatkan pertumbuhan, peningkatan ekspor juga akan mendorong pergerakan perekonomian negara, sebab ekspor negara dapat menarik banyak investasi, meningkatkan penyerapan tenaga kerja, dan memaksimalkan pemanfaatan sumber daya alam lokal.

Sejak tahun 2012 hingga 2016, ekspor indonesia terus mengalami penurunan. Berdasarkan data BPS, ekspor Indonesia mengalami penurunan dari 190.031.845.244 USD pada tahun 2012 menjadi 144.489.825.811 USD pada tahun 2016. Selama tahun tersebut, penurunan nilai ekspor yang terjadi juga diikuti dengan penurunan nilai impor Indonesia. Namun demikian ternyata laju penurunan nilai ekspor Indonesia lebih tinggi dibandingkan dengan laju penurunan impornya. Hal ini menyebabkan Indonesa sempat mengalami defisit neraca perdagangan di tahun 2012 hingga 2014.

Melihat kondisi tersebut, tentunya Indonesia perlu melakukan upaya strategis untuk meningkatkan kembali kinerja ekspornya. Salah satu upaya yang dapat dilakukan Indonesia adalah dengan melakukan pengembangan ekspor. Sebagai negara agraris yang unggul dalam produk pertanian, salah satu komoditas yang potensial digunakan untuk meningkatkan ekspor adalah rempah-rempah (Kemendag 2017).

Selama ini rempah Indonesia adalah salah satu komoditas yang paling banyak diekspor dengan kualitas terbaik di dunia. Diantara banyak komoditas rempah yang dihasilkan, komoditas kayu manis merupakan salah satu komoditas rempah yang dapat dimanfaatkan untuk mengembangkan ekspor. Pada tahun 2016 Indonesia menjadi salah satu dari lima eksportir kayu manis terbesar di pasar dunia (UN-Comtrade, 2018). Volume ekspor kayu manis Indonesia ke pasar dunia mencapai $48.899 .734 \mathrm{~kg}$ atau setara dengan $37.04 \%$ dari total ekspor kayu manis dunia. Besarnya kontribusi ekspor kayu manis Indonesia di pasar dunia tersebut menjadi potensi bagi pengembangan ekspor kayu manis.Berisi tentang latar belakang masalah, landasan teori, kajian dari penelitian-penelitian pendahulu, analisis masalah, serta tujuan penelitian.
Dalam perdagangan di pasar internasional, ekspor total kayu manis dunia selama tahun 2007 hingga tahun 2016 trennya cenderung meningkat. Total volume ekspor kayu manis di pasar dunia selama tahun 2007 hingga tahun 2016 rata-rata bertumbuh sebesar $4.04 \%$ per tahun. Sedangkan total nilai ekspor kayu manis di pasar dunia selama tahun 2007 hingga tahun 2016 rata-rata bertumbuh sebesar $11.63 \%$ per tahun. Pertumbuhan ini mengindikasikan bahwa potensi ekspor kayu manis di pasar dunia juga meningkat

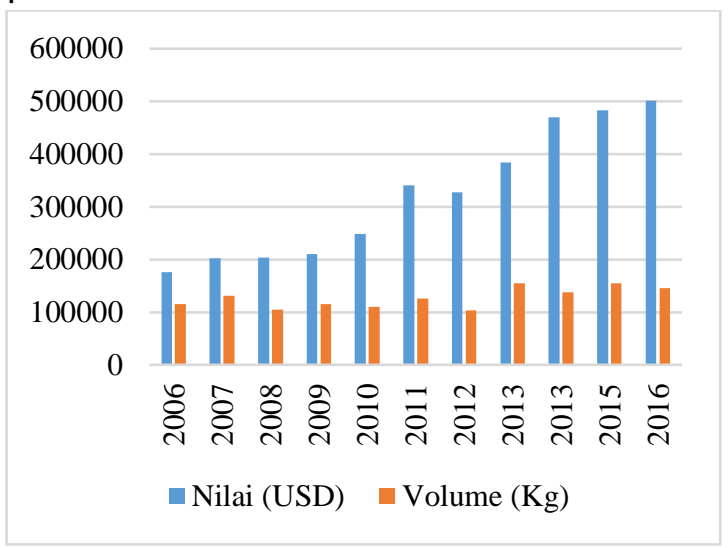

Gambar 1. Total Ekspor Kayu Manis di pasar dunia (USD)

Sumber: Comtrade, diolah

Volume ekspor dunia tertinggi selama tahun 2007 hingga tahun 2016 adalah sebesar 154.418.609 kg pada tahun 2013. Sedangkan total nilai ekspor dunia tertinggi di pasar internasional adalah sebanyak 500.832.827 USD pada tahun 2016.

Apabila kita melihat kondisi kayu manis di dalam negeri berdasarkan data Kementan, tren perkembangan produksi dan luas lahan kayu manis Indonesia beberapa tahun belakangan cenderung meningkat.

Tabel 1. Produksi dan luas lahan kayu manis Indonesia

\begin{tabular}{ccc}
\hline Tahun & $\begin{array}{c}\text { Produksi } \\
\text { (ton) }\end{array}$ & $\begin{array}{c}\text { Luas Lahan } \\
\left(\mathrm{m}^{2}\right)\end{array}$ \\
\hline 2010 & 88104 & 99321 \\
2011 & 90276 & 102125 \\
2012 & 89577 & 101797 \\
2013 & 92025 & 105504 \\
2014 & 91447 & 109645 \\
\hline
\end{tabular}

Sumber : Kementerian Pertanian (2017)

Produksi kayu manis Indonesia terbesar selama tahun 2010 hingga tahun 2014 adalah sebesar 91.447 ton pada tahun 2014. Sedangkan luas lahan kayu manis terluas selama tahun 2010 hingga tahun 2014 adalah seluas $109.645 \mathrm{~m} 2$ pada 
tahun 2014. Perkembangan produksi dan luas lahan tersebut tentu menjadi penopang sekaligus modal bagi pengembangan ekspor kayu manis Indonesia.

Melihat kinerja ekspor kayu manis Indonesia di pasar internasional, kinerja perdagangan kayu manis dunia di pasar internasional, serta produksi kayu manis dalam negeri, maka dirasa perlu untuk mengkaji tentang pengembangan ekspor kayu manis Indonesia.

Berdasarkan uraian tersebut di atas, maka tujuan dari penelitian ini adalah untuk menganalisis daya saing komoditas kayu manis sehingga ditemukan pasar ekspor yang optimis dan potensial untuk dikembangkan. Selain itu, penelitian ini juga menganalisis faktor apa saja yang mempengaruhi permintaan ekspor komoditas kayu manis tersebut.

\section{METODE PENELITIAN}

Penelitian tentang kayu manis ini akan memberikan kontribusi dengan melengkapi hasil penelitian yang sudah ada. Kebaruannya ada pada kebaruan data terkini, serta ragam pasar yang diteliti yang merupakan sepuluh pasar terbesar Indonesia.

Penelitian ini menggunakan data sekunder yang bersifat kuantitatif. Jenis data yang digunakan merupakan data panel yang terdiri dari data time series dan data cross section. Data time series terangkum dalam bentuk tahunan, yaitu data tahun 2007-2016 untuk metode RCA, EPD dan X-model, dan data tahun 2002-2016 untuk metode gravity. Sedangkan data cross section merupakan data sepuluh pasar ekspor utama kayu manis.

Data yang digunakan adalah data nilai ekspor, volume ekspor, PDB per kapita, populasi, tarif dan jarak. Data tersebut diperoleh dari United Nations of Comodity Trade Database (UN-Comtrade), World Development Indicators (WDI) World Bank, World Trade Organization (WTO) dan Cepii. Kode HS komoditas yang diteliti adalah 0906 (kayu manis). Dalam melakukan analisis pengembangan pasar dan produk ekspor rempah, penelitian ini menggunakan metode RCA, EPD, X-Model dan Gravity Model.

\section{Revealed Comparative Advantage (RCA)}

RCA merupakan salah satu metode yang digunakan untuk mengukur daya saing atau keunggulan komparatif di suatu wilayah. Adapun rumus dari RCA adalah sebagai berikut

$$
R C A=\frac{\left(X_{a j}\right) /\left(X_{t j}\right)}{\left(W_{a j}\right) /\left(W_{t j}\right)}
$$

dimana :

$\mathrm{X}_{\mathrm{aj}}$ :Nilai ekspor kayu manis Indonesia ke negara $\mathrm{j}$
$\mathrm{W}_{\mathrm{aj}} \quad$ :Nilai ekspor kayu manis dunia ke negara $\mathrm{j}$

$\mathrm{X}_{\mathrm{tj}} \quad$ :Nilai total ekspor Indonesia ke negara $\mathrm{j}$

Wtj :Nilai total ekspor dunia ke negara $\mathrm{j}$

Hasil perhitungan nilai RCA menunjukkan dua kemungkinan, yaitu bila nilai RCA lebih dari satu maka komoditas kayu manis di negara tersebut memiliki keunggulan komparatif sehingga memiliki nilai daya saing yang kuat. Apabila nilai RCA kurang dari satu maka dianggap memiliki daya saing lemah.

Export Product Dynamics (EPD)

EPD merupakan metode yang digunakan untuk mengukur posisi pasar dari produk suatu negara. Adapun rumus dari EPD adalah sebagai berikut:

Sumbu x: Pertumbuhan pangsa pasar ekspor negara $\frac{\sum_{t=1}^{t}\left(\left(\frac{X_{a j}}{W_{a j}}\right)_{t} \times 100 \%-\left(\frac{X_{a j}}{W_{a j}}\right)_{t-1} \times 100 \%\right)}{T}$

Sumbu y: Pertumbuhan pangsa pasar produk $\frac{\sum_{t=1}^{t}\left(\left(\frac{X_{t j}}{W_{t j}}\right)_{t} \times 100 \%-\left(\frac{X_{t j}}{W_{t j}}\right)_{t-1} \times 100 \%\right)}{T}$

dimana:

$\mathrm{X}_{\mathrm{aj}}$ :Nilai ekspor kayu manis Indonesia ke negara $\mathrm{j}$

$\mathrm{W}_{\mathrm{aj}} \quad$ :Nilai ekspor kayu manis dunia ke negara $\mathrm{j}$

$\mathrm{X}_{\mathrm{tj}} \quad$ :Nilai total ekspor kayu manis Indonesia ke negara j

$\mathrm{W}_{\mathrm{tj}} \quad$ :Nilai total ekspor dunia ke negara $\mathrm{j}$

$\mathrm{T}$ :Jumlah tahun

Hasil analisis daya saing kayu manis akan berada di salah satu dari keempat kuadran. Posisi komoditas tergantung pada daya tarik pasar dan kekuatan bisnis komoditas tersebut. Dengan matriks daya saing menggunakan EPD tersebut, dapat dilihat posisi daya saing masing-masing komoditas

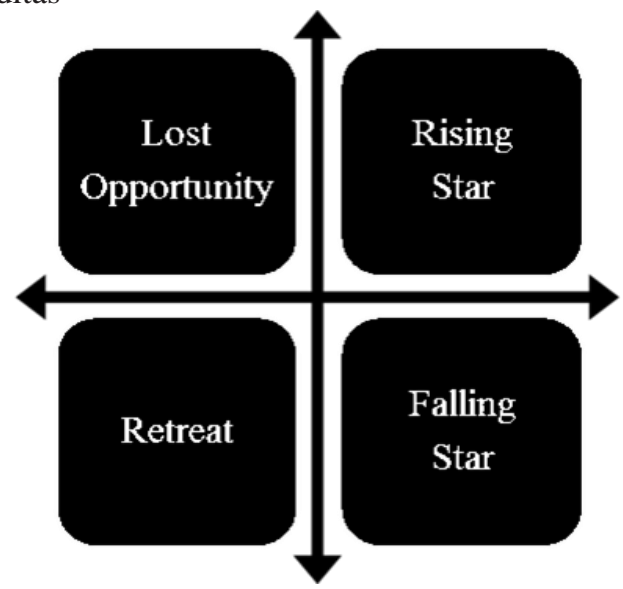

Gambar 2. Posisi daya saing produk dengan metode EPD

Sumber: Estherhuizen, 2006

X-Model Potential Export Products 
Metode ini menggabungkan hasil analisis metode RCA dengan hasil analisis metode EPD, dengan menggunakan metode ini hasil analisis daya saing yang diteliti menjadi lebih komprehensif karena melihat daya saing komoditas kayu manis Indonesia dari dua sisi sekaligus, yaitu dari sisi RCA dan juga EPD. Metode ini digunakan untuk melakukan klusterisasi potensi produk di wilayah tertentu. Klusterisasi ini dilakukan untuk memfokuskan pasar perdagangan

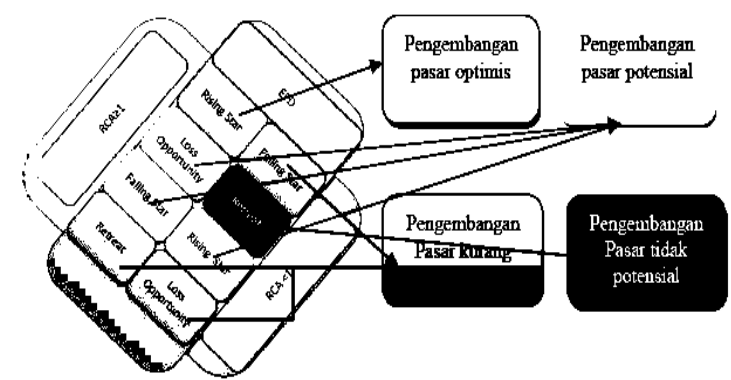

Gambar 3. Klusterisasi Analisis X-Model Potential Export Product

\section{Gravity Model}

Metode ini digunakan untuk menganalisis

faktor-faktor yang mempengaruhi ekspor komoditas kayu manis Indonesia ke negara tujuan. Penelitian ini menganalisis menggunakan data cross section yang terdiri dari sepuluh negara tujuan utama ekspor komoditas kayu manis dan data time series selama lima belas tahun. Adapun model yang digunakan adalah :

$$
\begin{aligned}
\ln X_{i j t}= & \beta_{0}+\beta_{1} \ln P D B C_{j t}+\beta_{2} \operatorname{lnPOP}_{j t}+\beta_{3} \ln \operatorname{lE}_{\mathrm{ijt}}+ \\
& \beta_{4} \operatorname{lnJE_{ijt}}+\beta_{5} \operatorname{lnTRF_{jt}}+\mathrm{u}_{\mathrm{ijt}}
\end{aligned}
$$

dimana :

$\begin{array}{ll}\mathrm{X}_{\mathrm{ijt}} & \text { : Volume ekspor }(\mathrm{kg}) \\ \mathrm{PDBC}_{\mathrm{jt}} & \text { : PDB perkapita (USD/Jiwa) } \\ \mathrm{POP}_{\mathrm{jt}} & : \text { Populasi (Jiwa) } \\ \mathrm{HE}_{\mathrm{ijt}} & \text { : Harga ekspor (USD/Kg) } \\ \mathrm{JE}_{\mathrm{ijt}} & \text { : Jarak ekonomi (Km) } \\ \mathrm{TRF}_{\mathrm{jt}} & : \text { Tarif impor (Persen) } \\ \mathrm{Ln} & \text { : Logarutma natural } \\ \mathrm{u}_{\mathrm{ijt}} & \text { : error term }\end{array}$

Adapun rumus untuk jarak ekonomi menurut Inayah et al (2015) adalah :

$\mathrm{JE}_{\mathrm{ij}}=\mathrm{DIS}_{\mathrm{ij}} \times \frac{\mathrm{PDB}_{\mathrm{j}}}{\sum \mathrm{PDB}_{j}}$

dimana :

$\mathrm{JE}_{\mathrm{ij}} \quad$ : Jarak ekonomi $(\mathrm{km})$

DIS $_{\mathrm{ij}} \quad$ : Jarak ibu kota negara $(\mathrm{km})$

$\mathrm{PDB}_{\mathrm{j}} \quad$ : PDB negara $\mathrm{j}$ (USD)

$\sum \mathrm{PDB}_{\mathrm{j}}$ : Total PDB negara $\mathrm{j}$ (USD)

\section{HASIL DAN PEMBAHASAN}

\section{Ekspor Kayu Manis Indonesia}

Selama tahun 2002 hingga 2016 Indonesia telah mengekspor kayu manis secara kontinyu ke 29 negara. Dari 29 negara tersebut, sepuluh pasar utama yang paling mendominasi ekspor kayu manis Indonesia adalah pasar Malaysia, Uni Emirat Arab, Kanada, Turki, Belanda, Jerman, Brazil, Amerika Serikat, Republik Dominika dan Aljazair. Selama lima belas tahun tersebut volume ekspor komoditas kayu manis Indonesia di pasar tujuan utama mengalami fluktuasi, namun demikian mayoritas pasar trennya cenderung mengalami peningkatan.

Dari seluruh pasar ekspor utama komoditas kayu manis Indonesia, pasar yang paling mendominasi volume ekspor komoditas ini adalah pasar Amerika Serikat. Total volume ekspor kayu manis ke pasar Amerika Serikat selama tahun 2002 hingga tahun 2016 adalah 28.616 ton. Sedangkan total volume ekspor di pasar Belanda adalah 56.501 ton, di pasar Brazil 37.030 ton, di pasar Malaysia 20.088 ton, di pasar Jerman 19.831 ton, di pasar Uni Emirat Arab 19.278 ton, di pasar Republik Dominika 18.529 ton, di pasar Kanada 12.327 ton, di pasar Turki sebanyak 11.262 ton, sedangkan total volume ekspor terendah adalah total volume ekspor ke pasar Aljzair, yaitu sebanyak 10.813 ton.

Rata-rata pertumbuhan volume ekspor terbesar adalah di pasar Aljazair, yaitu dengan besar rata-rata pertumbuhan sebesar 36.91 persen per tahun. Sedangkan pertumbuhan nilai ekspor terendah adalah pertumbuhan nilai ekspor di pasar Kanada dengan pertumbuhan sebesar -1.25 persen per tahun. Negatifnya pertumbuhan volume ekspor kayu manis Indonesia ke pasar Kanada disebabkan oleh volume ekspor yang cenderung terus menurun dari tahun ke tahun. Tabel 2 menunjukkan data volume ekspor kayu manis Indonesia ke sepuluh pasar utama. 
Mubarokah, I., Nurhayati, E.

Tabel 2. Volume ekspor kayu manis Indonesia ke sepuluh pasar utama (dalam ton)

\begin{tabular}{rrrrrrrrrrr}
\hline Tahun & Malaysia & \multicolumn{1}{c}{ UEA } & Kanada & \multicolumn{1}{c}{ Turki } & Belanda & Jerman & Brazil & \multicolumn{1}{c}{ AS } & Dom & Aljazair \\
\hline 2002 & 705 & 178 & 1017 & 146 & 3522 & 962 & 5130 & 14191 & 801 & 326 \\
2003 & 950 & 239 & 785 & 224 & 2938 & 1020 & 1276 & 14342 & 662 & 603 \\
2004 & 1169 & 294 & 1109 & 521 & 4033 & 1390 & 7726 & 15501 & 1147 & 298 \\
2005 & 1077 & 591 & 1183 & 262 & 6076 & 1476 & 1682 & 15324 & 934 & 467 \\
2006 & 1094 & 912 & 846 & 584 & 3523 & 1269 & 1392 & 19251 & 1186 & 304 \\
2007 & 1341 & 2343 & 1018 & 472 & 2378 & 1357 & 1710 & 18312 & 1011 & 821 \\
2008 & 1537 & 1170 & 903 & 431 & 2468 & 1424 & 1504 & 20732 & 1246 & 321 \\
2009 & 1449 & 1381 & 648 & 764 & 2276 & 1387 & 2113 & 16214 & 1314 & 518 \\
2010 & 1387 & 2306 & 634 & 1414 & 2299 & 1939 & 1431 & 20738 & 1440 & 2218 \\
2011 & 1422 & 1712 & 541 & 677 & 3878 & 1255 & 2120 & 21168 & 1472 & 646 \\
2012 & 1427 & 1787 & 673 & 1231 & 3584 & 1119 & 1900 & 15341 & 1431 & 697 \\
2013 & 1443 & 1292 & 739 & 985 & 4165 & 1185 & 1977 & 24144 & 1467 & 851 \\
2014 & 1874 & 2777 & 908 & 1109 & 7578 & 1659 & 2127 & 23541 & 1661 & 851 \\
2015 & 1481 & 1281 & 707 & 985 & 4395 & 1491 & 2297 & 21221 & 1437 & 1440 \\
2016 & 1730 & 1010 & 614 & 1456 & 3386 & 896 & 2645 & 21593 & 1317 & 491 \\
\hline Rata-rata & $7.74 \%$ & $28.20 \%$ & $-1.25 \%$ & $32.35 \%$ & $6.29 \%$ & $2.38 \%$ & $30.46 \%$ & $4.96 \%$ & $5.79 \%$ & $36.91 \%$ \\
Pertumbuhan & $149 \%$ &
\end{tabular}

Pada data nilai ekspor komoditas kayu manis Indonesia di pasar tujuan utama, secara keseluruhan rata-rata pertumbuhan nilai ekspornya adalah positif. Rata-rata pertumbuhan ekspor terendah adalah sebesar 10.96 persen, yaitu di pasar Kanada, sedangkan rata-rata pertumbuhan ekspor tertinggi adalah di pasar Turki, yaitu sebesar 46.80 persen.

Dari seluruh pasar ekspor utama komoditas kayu manis Indonesia, pasar yang paling mendominasi nilai ekspor komoditas ini adalah pasar Amerika Serikat. Total nilai ekspor kayu manis ke pasar Amerika Serikat selama tahun 2002 hingga tahun 2016 adalah 326.694 USD. Sedangkan total nilai ekspor di pasar Belanda adalah 62.901 USD, di pasar Brazil sebesar 31.768 USD, di pasar Jerman sebesar 23.926 USD, di pasar Malaysia sebesar 20.325 USD, di pasar Republik Dominika sebesar 17.384 USD, di pasar uni Emirat Arab sebesar 15.685 USD, di pasar Kanada sebesar 12.913 USD, di pasar Aljazair sebesar 11.606 USD, sedangkan total nilai terendah adalah total nilai ekspor ke pasar Turki, yaitu sebanyak 10.820 USD.

Total nilai ekspor kayu manis ke pasar Amerika Serikat selama tahun 2007 hingga tahun 2016 adalah 279766131 USD, dengan nilai ekspor terendah 14431583 USD dan nilai ekspor tertingginya 43335625 USD. Sedangkan total nilai ekspor terendah adalah total ekspor ke pasar Turki senilai 10057771 USD, dengan nilai ekspor terendah adalah 197763 USD dan nilai ekspor tertinggi adalah sebesar 2310386 USD. 
Mubarokah, I., Nurhayati, E.

Tabel 3. Nilai ekspor kayu manis Indonesia ke sepuluh pasar utama (dalam ribu USD)

\begin{tabular}{rrrrrrrrrrrr}
\hline Tahun & Malaysia & UEA & Kanada & Turki & Belanda & Jerman & Brazil & AS & Dom & Aljazair \\
\hline 2002 & 384 & 68 & 522 & 51 & 1630 & 522 & 2137 & 7879 & 358 & 168 \\
2003 & 506 & 109 & 364 & 100 & 1602 & 617 & 602 & 8297 & 239 & 330 \\
2004 & 1052 & 126 & 523 & 230 & 2348 & 886 & 3508 & 9076 & 458 & 160 \\
2005 & 585 & 263 & 634 & 116 & 1855 & 890 & 8053 & 8534 & 394 & 276 \\
2006 & 644 & 360 & 481 & 265 & 1672 & 951 & 6705 & 13230 & 471 & 172 \\
2007 & 935 & 904 & 667 & 246 & 1672 & 1138 & 893 & 15092 & 536 & 396 \\
2008 & 1371 & 498 & 786 & 198 & 1898 & 1298 & 1078 & 18233 & 866 & 275 \\
2009 & 1143 & 643 & 644 & 368 & 1754 & 1305 & 1173 & 14431 & 847 & 401 \\
2010 & 1209 & 1643 & 819 & 831 & 3287 & 2406 & 1164 & 22999 & 965 & 1367 \\
2011 & 1449 & 1581 & 1032 & 621 & 5105 & 2245 & 2259 & 29291 & 1259 & 830 \\
2012 & 1771 & 1439 & 904 & 1310 & 4371 & 1472 & 2194 & 19202 & 1412 & 833 \\
2013 & 1685 & 1408 & 1029 & 1091 & 5962 & 1713 & 2573 & 33815 & 1852 & 1226 \\
2014 & 2502 & 4006 & 1807 & 1605 & 13803 & 3551 & 3688 & 43335 & 2812 & 1722 \\
2015 & 2073 & 1515 & 1353 & 1476 & 8110 & 3022 & 4172 & 41763 & 2484 & 2572 \\
2016 & 3015 & 1121 & 1346 & 2310 & 6354 & 1909 & 4847 & 41601 & 2428 & 874 \\
\hline
\end{tabular}

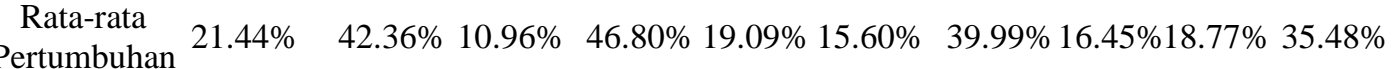

Berdasarkan data volume dan nilai ekspor kayu manis Indonesia ke sepuluh pasar utama tersebut, terlihat adanya perbedaan fluktuasi dan pertumbuhan pada volume ekspor dan nilai ekspor komoditas tersebut. Adanya perbedaan ini disebabkan oleh perubahan harga ekspor kayu manis dari tahun ke tahun di setiap negara. Kenaikan harga ekspor kayu manis setiap tahunnya menyebabkan laju pertumbuhan volume ekspor lebih lambat dibanding dengan laju pertumbuhan nilai ekspornya. Hal ini pulalah yang menjelaskan mengapa rata-rata pertumbuhan volume ekspor kayu manis Indonesia di pasar Kanada bernilai negatif, namun rata-rata pertumbuhan nilai ekspor di pasar Malaysia bernilai positif.

Tabel 4. Harga ekspor kayu manis Indonesia

\begin{tabular}{ccccccccccccc}
\hline Tahun & Malaysia & UEA & Kanada & Turki & Belanda & Jerman & Brazil & AS & Dom & Aljazair \\
\hline 2002 & 0.55 & 0.38 & 0.51 & 0.35 & 0.46 & 0.54 & 0.42 & 0.56 & 0.45 & 0.52 \\
2003 & 0.53 & 0.46 & 0.46 & 0.45 & 0.55 & 0.61 & 0.47 & 0.57 & 0.36 & 0.55 \\
2004 & 0.90 & 0.43 & 0.47 & 0.44 & 0.58 & 0.64 & 0.45 & 0.59 & 0.40 & 0.54 \\
2005 & 0.54 & 0.44 & 0.54 & 0.44 & 0.52 & 0.60 & 0.48 & 0.56 & 0.42 & 0.59 \\
2006 & 0.59 & 0.39 & 0.57 & 0.45 & 0.53 & 0.75 & 0.48 & 0.69 & 0.40 & 0.57 \\
2007 & 0.70 & 0.39 & 0.66 & 0.52 & 0.70 & 0.84 & 0.52 & 0.82 & 0.53 & 0.48 \\
2008 & 0.89 & 0.43 & 0.87 & 0.46 & 0.77 & 0.91 & 0.72 & 0.88 & 0.69 & 0.86 \\
2009 & 0.79 & 0.47 & 0.99 & 0.48 & 0.77 & 0.94 & 0.56 & 0.89 & 0.64 & 0.77 \\
2010 & 0.87 & 0.71 & 1.29 & 0.59 & 1.43 & 1.24 & 0.81 & 1.11 & 0.67 & 0.62 \\
2011 & 1.02 & 0.92 & 1.91 & 0.92 & 1.32 & 1.79 & 1.07 & 1.38 & 0.86 & 1.28 \\
2012 & 1.24 & 0.81 & 1.34 & 1.06 & 1.22 & 1.32 & 1.15 & 1.25 & 0.99 & 1.20 \\
2013 & 1.17 & 1.09 & 1.39 & 1.11 & 1.43 & 1.45 & 1.30 & 1.40 & 1.26 & 1.51 \\
2014 & 1.33 & 1.44 & 1.99 & 1.45 & 1.82 & 2.14 & 1.73 & 1.84 & 1.69 & 2.02 \\
2015 & 1.40 & 1.18 & 1.91 & 1.50 & 1.84 & 2.03 & 1.82 & 1.97 & 1.73 & 1.79 \\
2016 & 1.74 & 1.11 & 2.19 & 1.59 & 1.88 & 2.13 & 1.83 & 1.93 & 1.84 & 1.78 \\
\hline Rata-rata & $11.22 \%$ & $9.72 \%$ & $12.82 \%$ & $12.51 \%$ & $12.59 \%$ & $11.91 \%$ & $12.58 \%$ & $9.98 \%$ & $11.87 \%$ & $13.72 \%$ \\
\hline Pertumbuhan & & & & & & & & \multirow{2}{*}{1.59} \\
\hline
\end{tabular}


Harga komoditas kayu manis di setiap pasar pada setiap tahunnya cukup bervariasi. Adakalanya mengalami kenaikan namun adakalanya pula mengalami penurunan. Namun demikian secara rata-rata harga ekspor komoditas kayu manis di setiap pasar bertumbuh. Berdasarkan rata-rata harga ekspor kayu manis tahun 2002 hingga tahun 2016, rata-rata harga ekspor tertinggi adalah seharga 1.20 USD/kg di pasar Jerman, 1.14 USD/kg di pasar Kanada, 1.10 USD/kg di pasar Amerika Serikat, $1.05 \mathrm{USD} / \mathrm{kg}$ di pasar Belanda, $1.05 \mathrm{USD} / \mathrm{kg}$ di pasar Aljazair, $0.95 \mathrm{USD} / \mathrm{kg}$ di pasar Malaysia, 0.92 USD/kg di pasar Brazil, 0.86 USD/kg di pasar Republik Dominika, 0.79 USD/kg di pasar Turki, dan rata-rata harga terendah adalah sebesar 0.71 USD/kg di pasar Uni Emirat Arab.

\section{Analisis Daya Saing Kayu Manis Indonesia}

Berdasarkan hasil analisis dengan menggunakan metode RCA, selama periode 2007 sampai periode 2016, daya saing komoditas kayu manis Indonesia di setiap pasar memiliki keunggulan komparatif yang cukup bervariasi. Komoditas kayu manis memiliki nilai daya saing yang berbeda-beda di setiap tahun dan di setiap pasarnya. Namun secara keseluruhan komoditas kayu manis Indonesia di sepuluh pasar utama yang diteliti memiliki keunggulan komparatif dan berdaya saing yang kuat.

Hasil analisis rata-rata nilai RCA menunjukkan bahwa komoditas kayu manis memiliki keunggulan komparatif dan berdaya saing kuat di setiap tahun dan setiap pasar yang diteliti. Posisi daya saing dengan nilai keunggulan komparatif tertinggi berada di Republik Dominika dengan rata-rata nilai RCA sebesar 407.58, kemudian diurutan kedua dan seterusnya disusul dengan pasar Aljazair, Brazil, Kanada, Jerman, Turki, Amerika Serikat, Belanda, Uni Emirat Arab dan pasar Malaysia. Tabel 5 menunjukkan nilai RCA kayu manis Indonesia di sepuluh pasar tujuan utama.

Tabel 5. Nilai RCA kayu manis Indonesia di sepuluh pasar tujuan utama

\begin{tabular}{ccccccccccc}
\hline \multicolumn{1}{c}{ Tahun } & \multicolumn{10}{c}{ Negara } \\
\cline { 2 - 12 } & Malaysia & UEA & Kanada & Turki & Belanda & Jerman & Brazil & AS & Dominika Aljazair \\
\hline 2007 & 24.44 & 12.51 & 110.96 & 22.92 & 57.63 & 79.72 & 151.90 & 86.12 & 348.57 & 175.08 \\
2008 & 31.66 & 7.55 & 121.73 & 39.03 & 45.85 & 94.20 & 165.73 & 92.34 & 310.02 & 95.57 \\
2009 & 15.71 & 10.84 & 94.61 & 62.73 & 64.26 & 94.96 & 139.67 & 71.23 & 439.87 & 227.60 \\
2010 & 13.46 & 24.58 & 95.66 & 118.32 & 75.73 & 124.05 & 113.59 & 74.95 & 398.45 & 234.24 \\
2011 & 12.38 & 30.73 & 94.51 & 84.71 & 63.84 & 112.02 & 123.04 & 74.40 & 360.58 & 289.46 \\
2012 & 15.40 & 35.80 & 86.97 & 126.18 & 63.73 & 80.34 & 147.97 & 58.21 & 641.37 & 218.37 \\
2013 & 15.07 & 35.35 & 85.35 & 87.72 & 83.62 & 78.93 & 156.01 & 80.40 & 427.57 & 226.63 \\
2014 & 14.13 & 39.42 & 155.73 & 66.42 & 93.54 & 128.46 & 151.98 & 82.27 & 523.07 & 269.05 \\
2015 & 13.42 & 23.86 & 102.57 & 83.94 & 71.58 & 106.07 & 143.47 & 75.27 & 341.11 & 280.37 \\
2016 & 18.26 & 31.09 & 97.97 & 118.10 & 67.18 & 58.52 & 122.61 & 75.73 & 285.16 & 321.33 \\
\hline Rata- & 17.39 & 25.17 & 104.61 & 81.01 & 68.70 & 95.73 & 141.60 & 77.09 & 407.58 & 233.77 \\
rata & 17.93 &
\end{tabular}

Daya saing kayu manis Indonesia di sepuluh pasar tersebut perlu untuk terus dipertahankan bahkan ditingkatkan, terutama pada pasar-pasar yang meskipun rata-rata daya saingnya bernilai positif, namun rata-rata pertumbuhan daya saingnya bernilai negatif. Pasar-pasar tersebut adalah pasar Brazil dengan rata-rata pertumbuhan RCA sebesar -1.55 persen, dan pasar Amerika Serikat dengan rata-rata pertumbuhan RCA sebesar -0.04 persen per tahun.

Apabila merosotnya pertumbuhan RCA ini terus dibiarkan, tentu akan dapat menggerus daya saing komoditas kayu manis Indonesia di pasar tersebut. Beberapa faktor yang menyebabkan hal ini diantaranya adalah adanya perubahan pangsa pasar komoditas kayu manis Indonesia terhadap total ekspor Indonesia dan perubahan pangsa pasar komoditas dunia terhadap total ekspor dunia. Selain itu, fluktuasi juga disebabkan oleh perubahan pangsa pasar ekspor dari negara eksportir lainnya yang menjadi pesaing (Kusuma 2015).

Analisis lainnya mengenai daya saing komoditas kayu manis Indonesia dilakukan menggunakan metode EPD. Metode ini mengukur posisi pasar dari komoditas kayu manis Indonesia di pasar tujuan utama yang diteliti. Selain itu, metode ini juga dapat menunjukkan dinamis atau tidaknya kinerja komoditas kayu manis..

Pada hasil analisis EPD menunjukkan bahwa pasar ekspor komoditas kayu manis Indonesia berada pada posisi yang berbeda-beda, namun 
sebagian besar berada pada posisi rising star. Namun demikian tidak semua pasar ekspor komoditas kayu manis berada pada posisi yang menguntungkan, sebab beberapa pasar berada pada

Tabel 6 Hasil Analisis EPD kayu manis Indonesia tahun 2007-2016

\begin{tabular}{lccc}
\hline \multicolumn{1}{c}{ Negara } & $\begin{array}{c}\text { Pertumbuhan Pangsa Pasar } \\
\text { Ekspor }(\%)\end{array}$ & $\begin{array}{c}\text { Pertumbuhan Pangsa Pasar } \\
\text { Produk }(\%)\end{array}$ & Posisi Pasar \\
\hline Malaysia & 1.706 & 0.109 & Rising Star \\
UEA & 1.059 & -0.050 & Falling Star \\
Kanada & 0.348 & 0.002 & Rising Star \\
Turki & 3.444 & 0.048 & Rising Star \\
Belanda & 1.033 & 0.011 & Rising Star \\
Jerman & -0.019 & 0.003 & Lost Opportunity \\
Brazil & 0.276 & 0.012 & Rising Star \\
Amerika Serikat & 0.899 & 0.013 & Rising Star \\
Rep. Dominika & 3.014 & 0.010 & Rising Star \\
Aljazair & 0.120 & -0.021 & Falling Star \\
\hline
\end{tabular}

Ekspor komoditas kayu manis Indonesia berada pada posisi rising star di pasar Malaysia, Kanada, Turki, Belanda, Brazil, Amerika Serikat, dan Republik Dominika. Sedangkan di pasar Uni Emirat Arab dan Aljazair komoditas ini berada pada posisi falling star. Ini berarti bahwa komoditas kayu manis di Uni Emirat Arab dan Aljazair mengalami

Di pasar Jerman, pertumbuhan pangsa pasar ekspor komoditas kayu manis bernilai negatif disebabkan oleh terjadinya penurunan nilai ekspor kayu manis ke Jerman pada tahun 2016. Padahal di sisi lain, total impor kayu manis di pasar Jerman mengalami peningkatan pada tahun tersebut. Hal ini terjadi karena pada tahun tersebut Jerman lebih banyak mengimpor kayu manis dari pasar Belanda dibandingkan dari Indonesia. Selain itu, pada tahu 2016 Jerman juga mengimpor komoditas kayu manis dari beberapa importir baru, yaitu Irlandia, Lebanon, Slovenia dan Tanzania.

Setelah didapat hasil analisis RCA dan EPD, selanjutnya dilakukan klusterisasi potensi produk dengan menggunakan metode $\mathrm{x}$-model potential export products. Analisis ini dilakukan dengan mempertimbangkan hasil analisis RCA dan EPD yang telah didapat posisi falling star dan lost opportunity. Tabel 6 menampilkan hasil analisis perhitungan EPD di setiap pasar utama. kehilangan pangsa pasar produk. Hal ini tercermin dari nilai pertumbuhan pangsa pasar produk komoditas kayu manis yang bernilai negatif. Sedangkan di pasar Jerman, ekspor komoditas kayu manis Indonesia berada pada posisi lost opportunity. Ini berarti bahwa di pasar Jerman kehilangan pangsa pasar ekspor.

Tabel 7 Hasil analisis X-Model kayu manis Indonesia tahun 2007-2016

\begin{tabular}{|c|c|c|c|}
\hline Negara & RCA & EPD & $\begin{array}{c}\text { Potensi } \\
\text { Pengemb } \\
\text { angan } \\
\text { Pasar }\end{array}$ \\
\hline Malaysia & $\begin{array}{r}17 . \\
39\end{array}$ & Rising Star & Optimis \\
\hline UEA & $\begin{array}{r}25 . \\
17\end{array}$ & $\begin{array}{c}\text { Falling } \\
\text { Star }\end{array}$ & Potensial \\
\hline Kanada & $\begin{array}{r}104 \\
.61\end{array}$ & Rising Star & Optimis \\
\hline Turki & $\begin{array}{r}81 . \\
01\end{array}$ & Rising Star & Optimis \\
\hline Belanda & $\begin{array}{r}68 . \\
70\end{array}$ & Rising Star & Optimis \\
\hline Jerman & $\begin{array}{r}95 . \\
73\end{array}$ & $\begin{array}{c}\text { Lost } \\
\text { Opportunit } \\
y\end{array}$ & Potensial \\
\hline Brazil & $\begin{array}{r}141 \\
.60\end{array}$ & Rising Star & Optimis \\
\hline $\begin{array}{l}\text { Amerika } \\
\text { Serikat }\end{array}$ & $\begin{array}{r}77 . \\
09\end{array}$ & Rising Star & Optimis \\
\hline $\begin{array}{l}\text { Rep. } \\
\text { Dominika }\end{array}$ & $\begin{array}{r}407 \\
.58\end{array}$ & Rising Star & Optimis \\
\hline Aljazair & $\begin{array}{r}234 \\
.44 \\
\end{array}$ & $\begin{array}{c}\text { Falling } \\
\text { Star }\end{array}$ & Potensial \\
\hline
\end{tabular}


pengembangan pasar optimis di pasar Malaysia, Kanada, Turki, Belanda, Brazil, Amerika Serikat, dan Republik Dominika. Sedangkan di pasar Uni Emirat Arab, Jerman dan Aljazair ekspor komoditas kayu manis memiliki potensi pengembangan pasar potensial. Meskipun kayu manis Indonesia di pasar tersebut berada pada posisi lost opportunity atau falling star, namun pasar ini potensial untuk dikembangkan sebab komoditas kayu manis memiliki daya saing yang kuat di pasar tersebut.

Analisis Faktor-faktor yang Mempengaruhi Permintaan Kayu Manis Indonesia

Analisis faktor-faktor yang mempengaruhi permintaan ekspor kayu manis dilakukan menggunakan model gravity. Variabel penduga yang digunakan dalam analisis ini adalah variabel produk domestik bruto per kapita, populasi, harga ekspor, jarak ekonomi, dan tarif.

Analisis ini dimulai dengan perumusan model dan kemudian dilanjutkan dengan pemilihan model estimasi. Pemilihan model estimasi dilakukan dengan menggunakan uji Hausman yang bertujuan untuk memilih metode terbaik antara Random Effect Model (REM) atau Fixed Efect Model (FEM), dan dilakukan uji Chow yang digunakan untuk memilih metode terbaik antara Fixed Efect Model (FEM) atau Pooled Least Square (PLS). Berdasarkan hasil pengujian, pendekatan model terbaik yang dipilih adalah pendekatan model fixed effect.

Pengolahan dengan pendekatan model fixed effect ini juga dilakukan dengan pilihan kriteria pembobotan, yaitu dengan memberikan pembobotan SUR cross-section weighted. Metode ini mampu mengkoreksi masalah heteroskedastisitas dan autokorelasi antar unit cross section (Andari 2017). Berikut adalah hasil estimasi modelnya:

Tabel 8. Hasil estimasi faktor yang mempengaruhi ekspor kayu manis

\begin{tabular}{lcc}
\hline \multicolumn{1}{c}{ Variabel } & Koefisien & Probability \\
\hline C & -39.86222 & $0.0000^{*}$ \\
LNPDBC & 0.940168 & $0.0000^{*}$ \\
LNPOP & 2.901646 & $0.0000^{*}$ \\
LNHE & -0.232496 & $0.0000^{*}$ \\
LNJE & -1.035966 & $0.0000^{*}$ \\
TRF & -0.004434 & 0.7580 \\
\hline R-squared & \multicolumn{2}{c}{0.982685} \\
Adj R-squared & \multicolumn{2}{c}{0.980890} \\
\hline
\end{tabular}

Keterangan : * Signifikan pada taraf nyata $1 \%$

Berdasarkan hasil estimasi yang ditampilkan pada Tabel 8, nilai koefisien determinasi (R2) komoditas kayu manis adalah sebesar 0.982685 . Artinya bahwa 98.26 persen keragaman faktor- faktor yang mempengaruhi nilai ekspor komoditas kayu manis dapat dijelaskan oleh variabel-variabel bebasnya, sedangkan 1.74 persen sisanya dijelaskan oleh faktor-faktor di luar model.

Faktor-faktor yang signifikan mempengaruhi permintaan ekspor kayu manis adalah produk domestik bruto per kapita, populasi, harga ekspor, dan jarak ekonomi. Produk domestik bruto per kapita, populasi, harga ekspor, dan jarak ekonomi memiliki pengaruh yang signifikan pada taraf nyata satu persen. Sedangkan variabel tarif tidak memiliki pengaruh nyata pada ekspor komoditas kayu manis Indonesia.

Variabel produk domestik bruto per kapita negara tujuan berpengaruh positif terhadap ekspor kayu manis Indonesia, dimana setiap kenaikan PDB per kapita negara tujuan sebesar satu persen maka volume ekspor kayu manis akan meningkat sebesar 0.94 persen, begitu pula sebaliknya (ceteris paribus). PDB per kapita negara tujuan mencerminkan daya beli masyarakat, ini berarti bahwa peningkatan daya beli masyarakat di negara tujuan akan meningkatkan volume ekspor kayu manis Indonesia. Hal ini sesuai dengan hasil penelitian yang dilakukan oleh Andari (2017) yang berjudul Analisis Pengaruh dan Tingkat Keberhasilan Perdagangan Indonesia dalam ASEAN-India Free Trade Agrrement (AIFTA), dimana produk domestik bruto per kapita negara tujuan berpengaruh signifikan dan positif terhadap ekspor.

Variabel populasi negara tujuan berpengaruh positif terhadap ekspor kayu manis Indonesia, dimana setiap kenaikan populasi negara tujuan sebesar satu persen maka volume ekspor kayu manis akan meningkat sebesar 2.90 persen. Populasi negara tujuan mencerminkan besarnya pasar di negara tujuan, semakin besar pasar, maka akan semakin besar pula volume ekspor kayu manis Indonesia ke negara tujuan. Hal ini sesuai dengan penelitian Yuniarti (2007) yang berjudul Analisis Determinan Perdagangan Bilateral Indonesia Pendekatan Gravity Model, penelitian Telaumbanua (2011) yang berjudul Analisis determinan ekspor Provinsi Sumatera Utara: Pendekatan Gravity Model, dan penelitian Irgandhini \& Firdaus (2014).

Variabel harga ekspor memiliki pengaruh yang negatif, dimana setiap kenaikan harga sebesar satu persen maka volume ekspor akan menurun sebesar 0.23 persen. Meningkatnya harga ekspor membuat biaya yang dikeluarkan oleh negara tujuan menjadi lebih tinggi, hal ini akan menurunkan permintaan ekspor Indonesia sehingga volume ekspor kayu manis akan menurun. Namun 
demikian koefisien variabel harga menunjukkan bahwa kayu manis adalah barang yang inelastis, sehingga kebijakan menurunkan harga justru dapat mengurangi penerimaan ekspor. Karenanya untuk dapat meningkatkan penerimaan ekspor komoditas kayu manis, harga ekspor kayu manis perlu dijaga stabilitasnya. Hal ini sesuai dengan penelitian Tarman et al (2011). Penelitian tersebut menemukan bahwa harga merupakan salah satu faktor yang mempengaruhi permintaan ekspor. Pengaruh harga ekspor terhadap ekspor merupakan pengaruh yang memiliki hubungan negatif.

Variabel jarak ekonomi antara Indonesia dengan negara tujuan memiliki pengaruh yang negatif, dimana setiap kenaikan satu persen jarak ekonomi akan menurunkan volume ekspor sebesar 1.03 persen. Variabel jarak ekonomi mencerminkan biaya ekspor, sehingga meningkatnya jarak ekonomi mengakibatkan biaya yang dikeluarkan negara tujuan menjadi lebih tinggi, karenanya peningkatan jarak ekonomi akan menurunkan permintaan ekspor kayu manis. Hal ini juga ditemukan dalam penelitian Inayah et al (2015) yang berjudul The analysis of export determinant of indonesian pepper in the international market, yaitu jarak ekonomi antara negara asal dengan negara tujuan berpengaruh negatif terhadap ekspor. Demikian pula dengan hasil penelitian yang dilakukan oleh Pradipta dan Fridaus (2014), jarak ekonomi memiliki pengaruh negatif terhadap volume ekspor ke negara tujuan.

Pada variabel tarif, hasil analisis menunjukkan bahwa pemberlakuan tarif di negara tujuan ekspor kayu manis tidak berpengaruh signifikan. Hal ini ditunjukkan dengan nilai probabilitas variabel tarif lebih besar dari taraf nyata, yaitu $0.76>0.05$. Tidak signifikannya variabel tarif disebabkan karena persentase tarif di negara tujuan cenderung konstan. Selain itu, negara-negara dengan impor terbesar seperti Amerika Serikat, Malaysia, Belanda dan Jerman tidak melakukan pemberlakuan tarif bagi impor komoditas kayu manis Indonesia

\section{KESIMPULAN}

Ekspor sebagai salah satu komponen penting dalam perekonomian negara perlu menjadi salah satu fokus perhatian. Baiknya kinerja ekspor suatu negara akan berpengaruh positif bagi perekonomian negara. Ekspor dapat meningkatkan Produk Domestik Bruto, meningkatkan pertumbuhan ekonomi, menggerakkan roda perekonomian, membuka lapangan pekerjaan, serta meningkatkan kesejahteraan.
Sebagai salah satu upaya meningkatkan kinerja ekspor Indonesia, pemerintah dapat memanfaatkan kayu manis sebagai salah satu komoditas yang dapat dikembangkan. Berdasarkan hasil penelitian dengan mempertimbangkan analisis RCA dan EPD disimpulkan bahwa komoditas kayu manis memiliki potensi pengembangan pasar optimis di pasar Malaysia, Kanada, Turki, Belanda, Brazil, Amerika Serikat, dan Republik Dominika. Sedangkan potensi pengembangan pasar potensial bagi ekspor kayu manis adalah pasar Uni Emirat Arab, Jerman dan Aljazair.. Sehingga sebagai upaya mengembangkan ekspor, sebaiknya pemerintah dan eksportir memprioritaskan pengembangan ekspor pala dan kapulaga ke pasar-pasar yang memiliki potensi pengembangan pasar optimis sebagai prioritas pertama dan potensi pengembangan pasar potensial sebagai prioritas kedua.

Adapun faktor-faktor yang berpengaruh signifikan terhadap ekspor komoditas pala dan kapulaga adalah produk domestik bruto per kapita negara tujuan, populasi negara tujuan, harga ekspor dan jarak ekonomi. Variabel produk domestik bruto per kapita dan populasi memiliki hubungan yang positif terhadap ekspor, sedangkan variabel harga ekspor dan jarak ekonomi memiliki hubungan yang negatif terhadap ekspor. Sehingga apabila pemerintah dan eksportir akan melakukan pengembangan ekspor kayu manis ke pasar lain, sebaiknya pemerintah dan eksportir mempertimbangkan faktor-faktor yang signifikan mempengaruhi permintaan ekspor kayu manis tersebut

\section{DAFTAR PUSTAKA}

Andari W. 2017. Analisis Pengaruh dan Tingkat Keberhasilan Perdagangan Indonesia dalam ASEAN-India Free Trade Agreement (AIFTA). [tesis]. Bogor : Instiut Pertanian Bogor.

[BPS] Badan Pusat Statistik. 2017. Nilai Ekspor Impor Indonesia. https://www.bps.go.id/. (14 April 2017)

Estherhuizen, D. 2006. An Evaluation of The Competitiveness of the South African Agribusiness Sector. Journal University of Pretoria.

Inayah I., R Oktaviani., dan KD Heny. 2015. The Analysis of Export Determinant of Indonesian Pepper in the International Market. International Journal of Science and Research (IJSR). 5(11): 1856-1860.

Irgandhini AK, Firdaus M. Daya Saing Dan Permintaan Ekspor Produk Biofarmaka Indonesia di Negara Tujuan Utama Periode 
Mubarokah, I., Nurhayati, E.

2003-2012. Jurnal Manajemen dan Agribisnis. 11(3): 183-198

Kementerian Perdagangan. 2017. Sumber dari Internet Tentang Kemendag RI: Negara Tujuan Ekspor 10 Komoditas Potensial. http://www.kemendag.go.id/id/economicprofile/10-main-and-potentialcommodities/10potential-commodities. [13 April 2017].

Kusuma NA. 2015. Analisis Daya Saing dan Perdagangan Produk Ekspor Kelapa Sawit Indonesia di Pasar Internasional. [Tesis]. Bogor : Institut Pertanian Bogor.

Pradipta A, Firdaus M. Daya Saing dan Faktoraktor yang Memengaruhi Ekspor Buahbuahan Indonesia. Jurnal Manajemen dan Agribisnis. 11(2): 129-143

Tarman, Dewi K, Hari W, Umar F, Naufa M, Bambang SW. 2011. Kajian Kebijakan Pengembangan Diversifikasi Pasar dan Produk Ekspor. Laporan Akhir Kajian Kementerian Perdagangan Republik Indonesia, www.kemendag.go.id/files/pdf/2014/01/06/ Full-Report-Kajian-Diversifikasi.pdf

Telaumbanua E. 2012) Analisis determinan ekspor Provinsi Sumatera Utara: Pendekatan Gravity Model. Quantitative Economics Journal. 2(2): 35-52.

[UN-Comtrade] United Nations Commodity Trade. 2017 Statistics Database. https://comtrade.un.org/data. (14 April 2017].

Yuniarti D. (2007). Analisis determinan perdagangan bilateral indonesia pendekatan gravity model. Jurnal Ekonomi Pembangunan Kajian Ekonomi Negara Berkembang. 12 (2), 99-109. 